\title{
Treatment of ligno-cellulosic residues with urea. Influence of dosage, moisture, temperature and addition of ureases
}

\author{
F Muñoz, M Joy, R Faci, X Alibés * \\ Servicio de Investigacion Agraria, DGA, Aptdo, 727, Zaragoza, Spain
}

(Received 4 February 1991; accepted 14 October 1991)

\begin{abstract}
Summary - Comparative studies were made at a laboratory level to assess the effectiveness of the treatment of straw with anhydrous ammonia (anhydrous $\mathrm{NH}_{3}$ ) and urea. The influence of moisture, dosage, and temperature were also assessed. The influence of the addition of an urease source was studied in treatments with urea. Two experiments were performed: 1), Anhydrous- $\mathrm{NH}_{3}$ and urea were used separately to treat a total of 13 samples of barley straw. Anhydrous $\mathrm{NH}_{3}$ was applied to 3 samples at a dosage of $4 \%$ and at moisture levels of 9.2, 22.2 and $32.7 \%$. Urea was applied to 9 batches at doses at $4.3,6.5$ and $8.0 \%$ and at 3 moisture levels: $22.2,31.1$ and $42.7 \%$. One sample was left untreated. 2), Urea at a dosage of $3 \%$ was applied to 24 samples of wheat straw and 24 samples of maize stover at 4 moisture levels, $10,20,30$ and $40 \%$ and 3 temperatures: 15 , 25 and $35^{\circ} \mathrm{C}$ for wheat straw and 5,15 and $25^{\circ} \mathrm{C}$ for maize stover. All these parameters were studied both with and without the addition of crude soya bean (CSB).

In experiment 1 the increase in moisture content when $\mathrm{NH}_{3}$ was applied reduced the neutral detergent fibre (NDF) content, but did not modify the in vitro dry matter digestibility (IVDMD) values, which were similar to those obtained on the application of urea at moisture levels of 31.1 and $42.7 \%$. In experiment 2, the increase in moisture content to $30 \%$ produced a positive response in most of the chemical parameters analyzed. However, with an increase in humidity to $40 \%$ the results were less homogeneous. The temperatures used were not limiting, and only had a significant effect $(P<0.05)$ on the NDF and total nitrogen (N) contents. For maize stover the temperature did not influence $(P>$ $0.05)$ either the degree of ureolysis or the IVDMD. The addition of CSB had no significant effect $(P>$ $0.05)$ when applied to the maize stover, and when applied to wheat straw its only significant effects $(P<0.05)$ were on the NDF and IVDMD values. At low moisture levels the addition of CSB increased the degree of ureolysis in wheat straw.
\end{abstract}

straw / chemical treatment / anhydrous ammonia / urea / moisture / temperature / urease

Résumé - Traitement de résidus ligno-cellulosiques à l'urée. Influence de la dose, de l'humidlté, de la température et de l'addition d'uréase. Des essais comparatifs ont été effectuées à l'échelle d'un laboratoire, pour évaluer l'efficacité du traitement de la paille à l'ammoniac anhydre ou à l'urée, ainsi que l'influence de l'humidité, de la dose d'urée, de la température et de l'addition d'une source d'uréase dans le traitement à l'urée. On a réalisé 2 essais :

- sur 13 échantillons de $2 \mathrm{~kg}$ de paille d'orge, 3 traitements à l'ammoniac anhydre ont été effectués à une dose de $4 \%$ et à des niveaux d'humidité de $9,2,22,2$, et $32,7 \%$. On a effectué en outre 9 traitements à l'urée à 3 niveaux d'humidité $(22,2,21,1$ et $42,7 \%)$ et 3 doses d'urée $(4,3,6,5$ et 8,1\%); - 24 échantillons de paille de blé et 24 échantillons de cannes de maïs ont été traités à l'urée à $3 \%$, à 4 niveaux d'humidité $10,20,30$ et $40 \%, 3$ températures $\left(15,25\right.$ et $35^{\circ} \mathrm{C}$ pour la paille de blé et 5 , 15 et $24{ }^{\circ} \mathrm{C}$ pour les cannes de maïs) avec addition ou non de farine cru de soja (CSB), source d'uréase.

Dans l'expérience 1, on a observé que l'augmentation de l'humidité dans le traitement à l'ammoniac réduisait la teneur en NDF (fibre neutre détergente), mais qu'elle ne modifiait pas les valeurs de la

* Present address: IRTA, Passeig de Gracia 44, 08007, Barcelona, Spain 
IVDMD (dégradabilité de la matière sèche in vitro) qui étaient similaires à celles obtenues dans les traitements à l'urée à des niveaux d'humidité de 31,1 et $42,7 \%$.

Dans l'expérience 2, l'augmentation du taux d'humidité jusqu'à 30\% a provoqué une réponse positive de la plupart des paramètres analysés mais moins uniforme de 30 à $40 \%$. Les températures utilisées n'ont pas été limitantes, et ont eu un effet significantif $(P<0,05)$ sur les teneurs en NDF et en azote total (N). La température n'a eu d'influence ni sur le degré d'uréolyse, ni sur la IVDMD des cannes de maïs. L'addition de CSB n'a pas affecté $(P>0,05)$ l'efficacité du traitement des cannes de mais et n'a eu un effet significatif $(\mathrm{P}<0,05)$ que sur la teneur en NDF et la IVDMD de la paille de blé.

paille / traitement chimique / ammoniac-anydre / urée / humidité / température / urease

\section{INTRODUCTION}

Ligno-cellulosic residues are an important source of feed for ruminants in many parts of the world. They are produced in large quantities, but have a low nutritional value. Ways of improving their nutritional value which are compatible with the practical needs and practices of farmers are being investigated. The application of alkalis (Sundstel and Owen, 1984) has being developed unevenly over the last few decades. The most widely used treatment among farmers is the application of anhydrous $\mathrm{NH}_{3}$.

Hadjipanoyiotou (1982) used the addition of urea as an alternative to anhydrous $\mathrm{NH}_{3}$. The method was based on the fact that urea would turn into ammonia in the presence of adequate quantities of ureases under specific moisture and temperature conditions. To a large extent, these conditions determine the effectiveness of the method.

Existing information on the influence of moisture content and temperature on the application of anhydrous $\mathrm{NH}_{3}$ or urea is often contradictory (Borhami and Sundstøl, 1982; Cloete et al, 1983; Ørskov et al, 1983; Mandell et al, 1988). The addition of a source of urease to facilitate the process also produces results that are sometimes contradictory (Kiangi et al, 1981; Jayasuriya and Pearce, 1983; Williams et al, 1984b; Wanapat et al, 1985).
This paper attempts to determine the effects of treatments with urea on different materials at different levels of moisture content, temperature and dose, and the presence or not of a source of urease.

\section{MATERIALS AND METHODS}

\section{Experiment 1: Treatment of barley straw with anhydrous $\mathrm{NH}_{3}$ and urea}

Thirteen samples of $2 \mathrm{~kg}$ shredded $(2 \mathrm{~cm})$ barley straw (cv Georgia) were treated and kept in closed plastic bags $(60 \times 100 \mathrm{~cm})$. Three treatments with anhydrous $\mathrm{NH}_{3}(40 \mathrm{~g} / \mathrm{kg} \mathrm{DM})$ at moisture levels of 10,20 and $30 \%$ and 9 treatments with urea $(40,65$, and $80 \mathrm{~g} / \mathrm{kg} \mathrm{DM})$ at 3 moisture levels: 20,30 and $40 \%$.

The anhydrous $\mathrm{NH}_{3}$ treatments were injected directly into the bags containing the previously moistened straw. The urea treatments were applied manually as evenly as possible. The bags were closed and kept at laboratory temperature for 2 months.

Experiment 2: Influence of temperature, moisture and addition of crude soya bean (CSB) on the effectiveness of the treatment of different ligno-cellulosic materials with urea

Forty-eight $1.5-\mathrm{kg}$ samples of wheat straw (cv Anza) (WS) and maize stover (cv Pionner-3283) (CS) were treated with commercial urea $(46 \%$ 
Table I. Experimental design for urea solution treatments on wheat straw and maize stover, applied in plastic containers (Exp 2).

\begin{tabular}{|c|c|c|c|c|c|}
\hline \multicolumn{3}{|c|}{ Wheat straw (WS) } & \multicolumn{3}{|c|}{ Maize stover (CS) } \\
\hline $\begin{array}{l}\text { Temp } \\
\left({ }^{\circ} \mathrm{C}\right)\end{array}$ & $C S B$ & $\begin{array}{l}\text { Moisture } \\
\text { (\%) }\end{array}$ & $\begin{array}{l}\text { Temp } \\
\left({ }^{\circ} \mathrm{C}\right)\end{array}$ & $\operatorname{CSB}$ & $\begin{array}{l}\text { Moisture } \\
\text { (\%) }\end{array}$ \\
\hline 15 & $\begin{array}{l}* \\
- \\
\bar{*} \\
\overline{-} \\
- \\
-\end{array}$ & $\begin{array}{l}11.6 \\
10.9 \\
24.2 \\
25.2 \\
36.3 \\
38.0 \\
47.9 \\
44.7\end{array}$ & 5 & $\begin{array}{l}* \\
- \\
- \\
\vdots \\
- \\
-\end{array}$ & $\begin{array}{l}15.2 \\
15.5 \\
26.0 \\
26.0 \\
39.2 \\
36.0 \\
51.8 \\
54.2\end{array}$ \\
\hline 25 & $\begin{array}{l}* \\
- \\
- \\
- \\
- \\
-\end{array}$ & $\begin{array}{l}13.3 \\
13.3 \\
25.2 \\
25.8 \\
38.6 \\
39.2 \\
51.0 \\
50.7\end{array}$ & 15 & $\begin{array}{l}* \\
\bar{z} \\
\bar{z} \\
- \\
-\end{array}$ & $\begin{array}{l}15.2 \\
16.1 \\
29.8 \\
30.0 \\
39.9 \\
41.9 \\
50.8 \\
49.9\end{array}$ \\
\hline 35 & $\begin{array}{l}* \\
\overline{-} \\
\bar{*} \\
- \\
-\end{array}$ & $\begin{array}{l}12.7 \\
12.9 \\
23.9 \\
23.6 \\
36.5 \\
36.9 \\
49.0 \\
51.7\end{array}$ & 25 & $\begin{array}{l}\star \\
- \\
\star \\
\vdots \\
\vdots \\
-\end{array}$ & $\begin{array}{l}14.5 \\
15.6 \\
28.2 \\
27.9 \\
39.5 \\
41.4 \\
50.5 \\
48.4\end{array}$ \\
\hline
\end{tabular}

* Crude soya bean added (CSB).

nitrogen). Table I shows the different temperature and moisture conditions, and whether or not CSB was added. Temperatures were chosen for their similarity to ambient temperatures at different harvest times. The urea doses applied were $30 \mathrm{~g} / \mathrm{kg}$ DM (WS) and $32.5 \mathrm{~g} / \mathrm{kg}$ DM (CS), and the CSB doses were $33 \mathrm{~g} / \mathrm{kg}$ DM (WS) and 35 $\mathrm{g} / \mathrm{kg} \mathrm{DM}$ (CS).

All the samples were shredded in a hammer mill through a $2-\mathrm{cm}$ diameter sieve. The treatments were performed manually. The treated material was kept in double-capped plastic containers for 2 months in 4 climatic chambers at a constant temperature.

\section{Chemical and biological analysis}

After drying in a ventilated oven at $60^{\circ} \mathrm{C}$ the samples were ground in a bladed mill through a $0.8-\mathrm{mm}$ sieve. The following parameters were 
analyzed: ash, crude fibre (CF) and total nitrogen (N) (AOAC, 1984); neutral detergent fibre (NDF) (Goering and Van Soest, 1970); unhydrolysed urea (Watt and Chrisp, 1954); in vitro dry matter digestibility (IVDMD) (Tilley and Terry, 1963); organic matter or dry matter cellulase digestibility * (OMD or DMD-cellulase) (Aufrere, 1982); in sacco dry matter degradability (48 h) (DMD, in sacco) using 4 rumen fistulated wethers (Mehrez and Ørskov, 1977).

\section{Statistical analysis}

The results obtained were subjected to variance analysis (Steel and Torrie, 1980) using the statistical analysis system (SAS) (1987). Since repetitions were lacking, triple interaction was taken as error. To determine the main effects, nonsignificant double interactions were added to the error. When the double interaction was significant, analysis was not continued (Baucroft, cited by Sokal and Rohlf, 1979).

\section{RESULTS}

\section{Experiment 1}

Table II shows the results of the chemical parameters analyzed. In treatment with anhydrous $\mathrm{NH}_{3}$ the increased moisture caused a reduction in NDF content of 4.3, 10.5 and 13.5 percentage units for moisture levels of $9.2,22.2$ and $32.7 \%$ respectively.

In the treatments with urea (table II) the presence of variable amounts of residual urea permitted an estimation of the degree of ureolysis achieved. A positive response was obtained in line with moisture. At a moisture level of around $40 \%$, ureolysis was practically total, while at around $20 \%$ moisture the degree of ureolysis was be- tween $30-50 \%$. On the other hand, increasing the dose of urea brought about a negative response in ureolysis.

Crude fibre and ash contents were apparently unaffected by the urea treatments, and NDF content decreased. This tendency was greater at the intermediate moisture level $(30 \%)$. The results obtained by means of IVDMD and OMD-cellulase also showed some degree of moisture influence, and coincided with the largest falls in NDF content.

\section{Experiment 2}

Table III shows the effects of temperature, moisture and CSB application on the chemical values carried out on the urea treatment of wheat straw and corn stover. The analytic values of these treatments are shown in figures 1 and 2 .

\section{Wheat-straw treatments}

The increase in temperature $(15,25$ and $35^{\circ} \mathrm{C}$ ) caused a reduction in $\mathrm{OM}$ content $(92.4,90.8,90.7 \%)(P<0.001)$, an increase in total $N(0.95,1.01,1.32 \%)(P<$ 0.001 ) and a reduction in NDF content $(78.6,76.1,75.8 \%)(P<0.001)$.

The effect of moisture gave a clear response $(P<0.001)$ in total $\mathrm{N}$ content, where it was $1.42,1.01,0.99$ and $0.97 \%$ respectively for moisture levels of 10,20 , 30 and $40 \%$. The degree of ureolysis is influenced by moisture content; however, there is an interaction $(P<0.01)$ with the temperature and the presence of ureases. The DMD-cellulase and DMD in sacco parameters were affected $(P<0.01, P<$ $0.05)$ by the moisture content, with temperature-urease interactions $(P<0.05)$.

\footnotetext{
- Onuzuka R 108 Yakult Pharmaceutical Industry Co Ltd 21 Japan.
} 
Treatment of ligno-cellulosic residues with urea

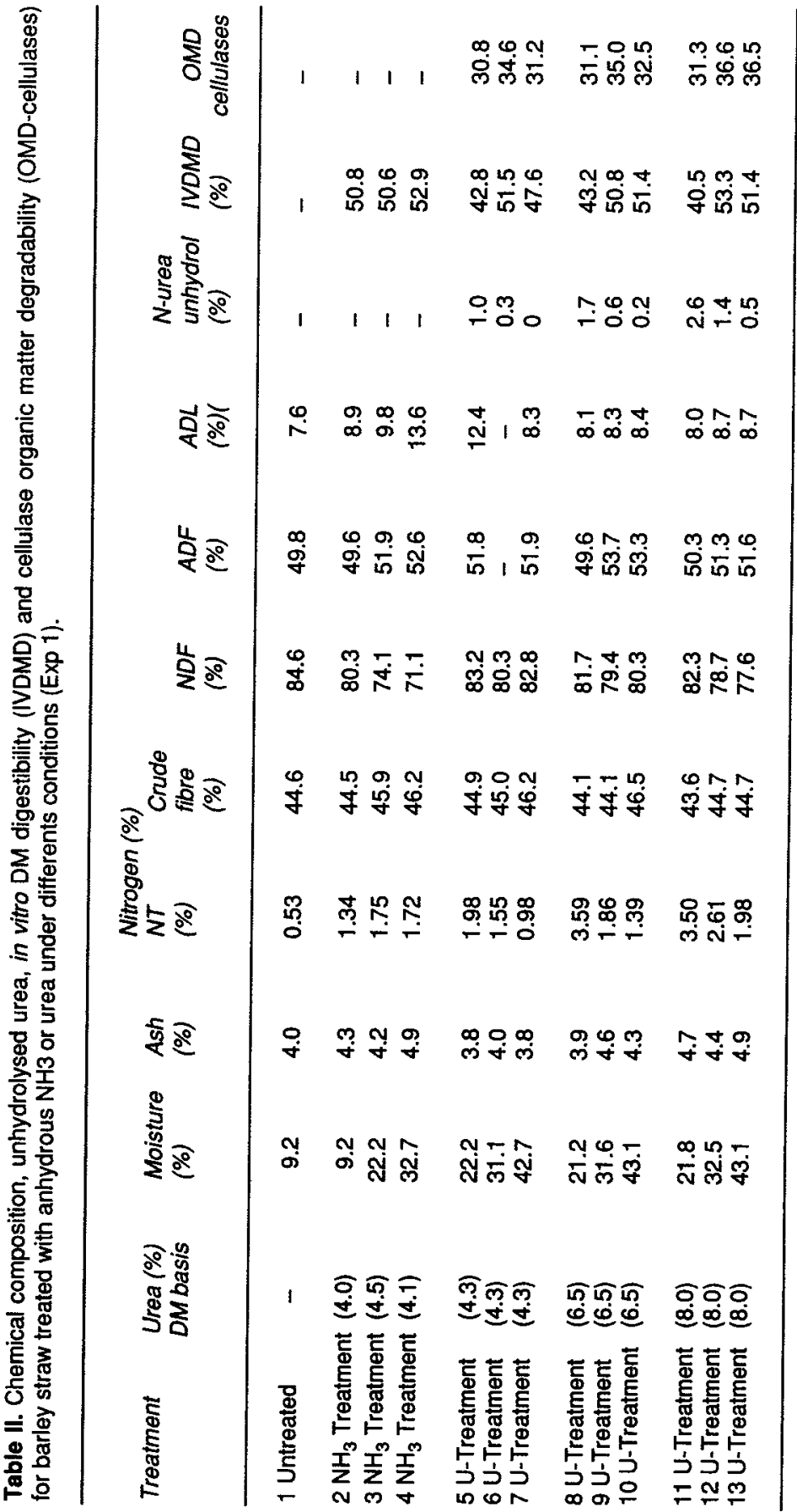


Table III. Significance of the effects of temperature, moisture and urease application on different parameters (Exp 2).

\begin{tabular}{|c|c|c|c|c|c|c|c|}
\hline Neutral & $\begin{array}{l}\text { Organic } \\
\text { matter }\end{array}$ & $\begin{array}{l}\text { Deterg } \\
\text { fibre }\end{array}$ & $\begin{array}{l}\text { N-urea } \\
\text { resid }\end{array}$ & Total N & IVDMD & $\begin{array}{c}D M D \\
\text { cellulases }\end{array}$ & $\begin{array}{c}D M D \\
\text { in sacco }\end{array}$ \\
\hline \multicolumn{8}{|c|}{ Wheat straw treatments } \\
\hline Temperature (T) & $* * *$ & $* * *$ & - & $* * *$ & - & - & - \\
\hline Moisture (M) & NS & NS & - & $\star * *$ & - & ** & * \\
\hline Urease (U) & NS & $\star \star \star *$ & - & NS & * & - & - \\
\hline \multicolumn{8}{|l|}{ Interactions : } \\
\hline$(\mathrm{T} \times \mathrm{M})$ & NS & NS & $* *$ & NS & * & NS & NS \\
\hline$(T \times U)$ & NS & NS & NS & NS & NS & " & * \\
\hline$(M \times U)$ & NS & NS & $* \star$ & NS & NS & NS & NS \\
\hline $\mathrm{x}$ & 91.30 & 76.83 & 0.30 & 1.10 & 29.26 & 27.15 & 44.19 \\
\hline Root MSE & 0.430 & 1.040 & 0.065 & 0.117 & 1.660 & 0.983 & 3.347 \\
\hline \multicolumn{8}{|c|}{ Corn stover treatments } \\
\hline Temperature (T) & * & "* & NS & * & NS & - & - \\
\hline Moisture (M) & NS & NS & $* * *$ & ** & NS & ** & - \\
\hline Urease (U) & NS & NS & NS & NS & NS & - & NS \\
\hline \multicolumn{8}{|l|}{ Interactions : } \\
\hline$(T \times M)$ & NS & NS & NS & NS & NS & NS & $* * \star$ \\
\hline$(T \times U)$ & NS & NS & NS & NS & NS & ** & NS \\
\hline$(M \times U)$ & NS & NS & NS & NS & NS & NS & NS \\
\hline$\times 90.65$ & 72.75 & 0.28 & 1.48 & 46.32 & 34.93 & 53.43 & \\
\hline Root MSE & 1.047 & 1.865 & 0.183 & 0.207 & 4.527 & 1.163 & 2.204 \\
\hline
\end{tabular}

Significance : $P<0.05 ;{ }^{*} P<0.001$ and NS $=P>0.05 ;$ MSE $:$ mean square error.

The application of CSB caused a reduction in NDF content $(P<0.001)$, with a reduction from 77.7 to $75.9 \%$, and a slight increase $(P<0.05)$ in the IVDMD value. It had no effect on the total $\mathrm{N}$ content $(P>$ 0.05).

\section{Maize stover treatments}

With the increase in temperature (table III) there were changes in total $\mathrm{N}(P<0.05)$ and NDF $(P<0.01)$. There were no changes in the degree of ureolysis or in the IVDMD $(P<0.05)$. On average, at temper- atures of 5,15 and $25^{\circ} \mathrm{C}$, NDF was 71.8 , 74.8 and $71.7 \%$, and total $N$ content was $1.39,1.47$ and $1.63 \%$ respectively.

The increases in moisture level led to a considerable drop in the residual urea content $(P<0.001)$ (from 0.84 to $0.08 \%$ of $N$, on average), and the total $\mathrm{N}$ content decreased $(P<0.01$ ) (from 1.81 to $1.40 \%$ of $N)$. There was a significant variation in DMD-cellulase $(P<0.01)$ with increases in moisture content $(33.2,35.9,36.1$ and $34.6 \%$ respectively for the 4 moisture levels). The application of ureases caused no significant response $(P<0.05)$ in any of the parameters studied. 

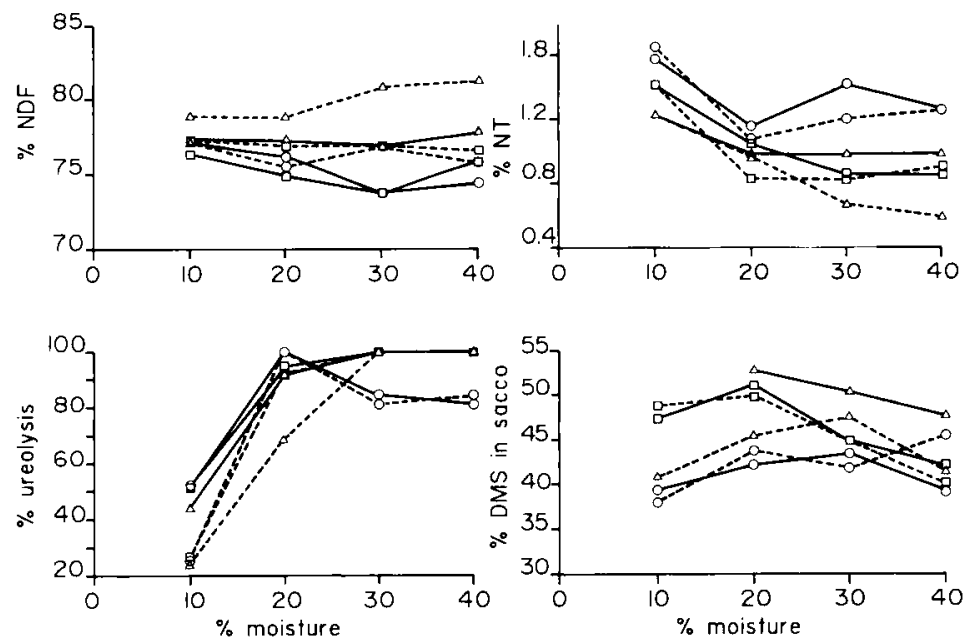

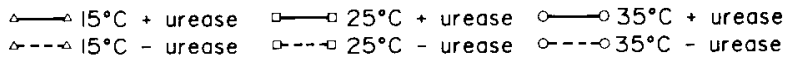

Fig 1. Neutral detergent fibre (NDF) and total $N$ contents, urea hydrolysation rate, dry matter degradability in sacco ( $48 \mathrm{~h}$ ) (DMD- in sacco) from wheat straw treated with $3 \%$ urea at 3 different temperatures and four levels of moisture (Exp 2).
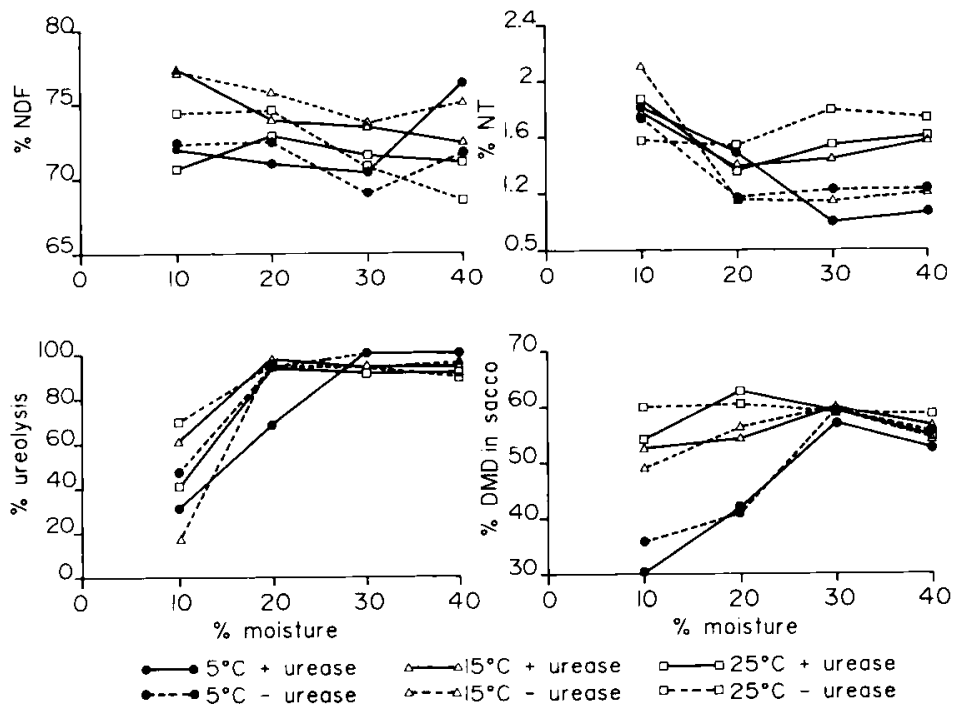

Fig 2. Neutral detergent fibre (NDF) and total $N$ contents, urea hydrolysation rate, dry matter degradability in sacco (48 h) (DMD- "in sacco") from maize stover treated with $3 \%$ urea at 3 different temperatures and 4 levels of moisture (Exp 2). 


\section{DISCUSSION}

\section{Anhydrous $\mathrm{NH}_{3}$ treatment vs urea treatment}

In anhydrous $\mathrm{NH}_{3}$ treatment, the variation in moisture content did not affect the IVDMD, although there was less $\mathrm{N}$ retained in the driest treatment. This coincides with the findings of Waiss et al (1972) and Solaiman et al (1979) who used ammonia in an aqueous solution, and with Kiangi et al (1981) and Mandell et al (1988) who used higher moisture levels. According to Borhami and Sundstel (1982) increases in moisture of up to $10 \%$ would give positive responses, and the addition of more water would only be necessary if very high doses of ammonia were employed, which would lead to the retention of a quantity of $N$ which would be unsuitable for animal nutrition (Dryden and Leng, 1986). In practical conditions of treatment with anhydrous $\mathrm{NH}_{3}$, lbbotson et al $(1983,1984)$ found no influence due to moisture content.

The increase in the residual urea and total $\mathrm{N}$ content with the increase of the urea dose coincides with the findings of Jayasuriya and Pearce (1983) who estimated the maximum dose of urea at $6 \%$, at moisture levels higher than those studied here. There was no influence of the 3 doses of urea on the IVDMD and OMDcellulase. This coincides with the observations of Williams et al (1984a) in in sacco results and of Abdouli and Khorchani (1987) for in vitro results with treatments at $37^{\circ} \mathrm{C}$. There could be a tendency for the NDF content to decrease when the urea dose is increased. This coincides with the results of Abdouli and Khorchani (1987). The values obtained in IVDMD for anhydrous $\mathrm{NH}_{3}$ treatments are comparable to those obtained with urea at $40-60 \mathrm{~g} / \mathrm{kg}$ DM and $30 \%$ moisture content.

\section{Influence of moisture on urea treatment}

The increase in moisture content caused an increase in the degree of ureolysis and greater nitrogen retention. In WS the application of ureases at low moisture levels had a positive effect on the degree of ureolysis. This coincides with the findings of Besle et al (1990a,b). However in CS the application of ureases did not have any effect. Williams et al (1984a), working at moisture levels of between $25-35 \%$, also observed a greater degree of ureolysis with increased moisture.

In general, both experiments (ie, 1 and 2) were more effective when the moisture content was raised from 20 to $30 \%$. However, increasing moisture to $40 \%$ did not lead to better results in all cases. Ibrahim et al (1986) also estimated optimum moisture content to be $\approx 30 \%$.

\section{Influence of temperature}

In the anhydrous $\mathrm{NH}_{3}$ treatments carried out in stack, Alibes et al (1984) refer to the necessity of high ambient temperatures to produce optimum results and, in particular, good nitrogen retention. Thus, the limited effectiveness of some treatments (Mandell et al, 1988; Mann et al, 1988) has been attributed to low temperatures. It is reasonable to consider, therefore, that in treatments with urea in which the temperature does not rise due to the treatment, ambient temperature is a factor which determines successful treatment.

Temperature increase (between 5$35^{\circ} \mathrm{C}$ ) was not decisive in determining the specific degree of ureolysis, but did seen to determine the accompanying greater nitrogen retention. Cloete and Kritzinger (1984) did not observe sufficient ureolysis at $4{ }^{\circ} \mathrm{C}$; Bennahmed and Dulphy (1985) and Besle et al (1990b), working in low winter temperatures, observed ureolysis of 
19 and $17 \%$. However, Williams et al (1984b) indicated that there could be sufficient ureolysis at $5.5^{\circ} \mathrm{C}$, although the process would be slower.

In our experiments, none of the temperatures used had an important effect on the process. However, at extreme temperatures $\left(5\right.$ and $\left.35^{\circ} \mathrm{C}\right)$ there are occasional interactions which should be taken into account. On the other hand, Cottyn and $\mathrm{De}$ Boever (1988) did not achieve effective treatments at an average daily temperature of $5^{\circ} \mathrm{C}$.

\section{Influence of adding ureases}

In general, the effects on digestibility and other chemical/biological parameters of adding a urease source was little or none (Kiangi et al, 1981; Jayasuriya and Pearce, 1983; Wanapat et al, 1985; Williams et al, 1984b). This could be due to the great diversity of added CSB sources (Ibrahim et al, 1986) to the wide variety of dosages applied: $6 \mathrm{~g} / \mathrm{kg}$ DM (Dias Da Silva et al, 1988); $50 \mathrm{~g} / \mathrm{kg} \mathrm{DM}$ (Williams et al, 1984b) and of moisture content. The presence of ureases considerably reduces the treatment time (Jayasuriya and Pearce, 1983; Williams et al, 1984b). On the other hand, the best responses have been shown by Besle et al (1990a), where moisture content was reduced to $20-25 \%$; these responses not only affected ureolysis, OMD and $\mathrm{N}$ retention but also intake (for reasons still to be identified).

In maize stover treatments there was no response likely to the addition of 3\% CSB, whereas in wheat straws treatments there were some changes. Cloete and Kritzinger (1984) found worse results at $35^{\circ} \mathrm{C}$ and according to them this could be due to the reduction in ureasic activity at this temperature.This coincides with Du Preez 1983 (cited by Cloete and Kritzinger, 1984), who concluded that ureases showed the greatest activity at $30^{\circ} \mathrm{C}$.

\section{CONCLUSION}

Treatment with urea in an aqueous solution has always improved the nutritional quality of the original by-product. The factors studied (dosage, moisture content, temperature and presence of ureases) play a fundamental role. These treatments could be applied specifically in tropical or arid climates, and would adapt particularly well to Mediterranean climates. In this group of climatic regions, it could prove of interest to reduce as far as possible the amount of water applied. This seems to be possible (optimum moisture levels between 25 and $30 \%$ ), even at lower moisture levels, where additional ureases would have to be used.

A $4 \%$ urea dose seems to be optimum, and the range of temperatures studied (5$35{ }^{\circ} \mathrm{C}$ ) is compatible with the treatment. The ureolytic activities of the straws used is probably sufficient, making the addition of ureases unnecessary.

\section{ACKNOWLEDGMENTS}

The authors wish to thank the CICYT, CEE-STD and CONAI for funding this work, and $\mathrm{J}$ Perez Revuelto, T Fustero and A Legua for their help in carrying it out.

\section{REFERENCES}

Abdouli $H$, Khorchani $T$ (1987) Traitement des pailles à l'urée. I. Conditions d'utilisation de l'urée, source d'ammoniac, dans le traitement de la paille. Fourrages 110, 205-218

Alibes X, Muñoz F, Faci R (1984) Anhydrous ammonia-treated cereal straw for animal 
feeding. Some results from the Mediterranean area. Anim Feed Sci Technol 10, 239-246

AOAC (1984) Official Methods of Analysis. Association of Analytical Chemists, Arlington, USA, 14th edn

Aufrere J (1982) Étude de la prévision de la digestibilité des fourrages par une méthode enzymatique. Ann Zootech 31(2), 111-130

Benhamed H, Dulphy JP (1985) Note sur la valeur azotée de fourrages pouvres traités par l'urée ou l'ammoniac. Ann Zootech 34(3), 335-346

Besle JM, Chenost $M$, Tisserand JL, Lemoine JP, Faurie F, Grenet N (1990a) Ammoniation of straw by urea: extent of ureolysis and improvement of nutritive value with moderate water addition. Reprod Nutr Dev (suppl 2), 174

Besle JM, Zwaenepoel P, Chenost M, Beaulieu G, Tisserand JL, Faurie F, Grenet N (1990b) Ammoniation of straw by urea: influence of addition of soybeans and/or molasses on characteristics of treatment. Reprod Nutr Dev (suppl 2), 175

Borhami BEA, Sundstøl F (1982) Studies on ammonia-treated straw. I. The effects of type and level of ammonia, moisture content and treatment time on the digestibility in vitro and enzyme soluble organic matter of oat straw. Anim Feed Sci Technol 7, 45-51

Cloete SWP, De Veliers TT, Kritzinger NM (1983) The effect of temperature on the ammoniation of wheat straw by urea. S Afric $J$ Anim Sci 13(3), 202-203

Cloete SWP, Kritzinger MM (1984) A laboratory assessment of various treatment conditions affecting the ammoniation of wheat straw by urea. 1. The effect of temperature, moisture level and treatment period. $S$ Afric $J$ Anim Sci 14(2), 55-58

Cottyn BG, De Boever JL (1988) Upgrading of straw by ammoniation. Anim Feed Sci Technol 21, 287-294

Dias Da Silva A, Mascarenhas-Ferreira A, Guedes VM (1988) Effects of moisture level, treatment time and soya bean addition on the nutritive value of urea-treated maize stover. Anim Feed Sci Technol 19, 67-77

Dryden G, MCL, Leng RA (1986) Treatment of barley straw with ammonia and sulphur diox- ide gases under laboratory conditions. Anim Feed Sci Technol 14, 41-54

Goering HK, Van Soest PJ (1970) Forage Fiber Analysis. USDA ARS Agric Handbook 379, 1-12

Hadjipanayiotou M (1982) The effect of ammoniation using urea on the intake and nutritive value of chopped barley straw. Grass \& Forage Sci 37, 89-93

Ibbotson CF, Mansbrindge $\mathrm{R}$, Adamson $\mathrm{AH}$ (1983/1984) Commercial experience of treating straw with ammonia. Anim Feed Sci Technol 10, 223-228

Ibrahim MNM, Schiere JB, Pereaa HGD (1986) Effect of method of urea solution application on the nutritive value of treated rice straw. Agric Wastes 18, 225-232

Ibrahim MNM, Tamminga S, Zemmelink G (1989) Effect of urea treatment on rumen degradation, characteristics of rice straws. Anim Feed Sci Technol 24, 83-95

Jayasuriya MC N, Pearce GR (1983) The effect of urease enzyme on treatment time and the nutritive value of straw treated with ammonia as urea. Anim Feed Sci Technol 8, 271-281

Kiangi EMI, Kategile JA, Sundstel F (1981) Different sources of ammonia for improving the nutritive value of low quality roughages. Anim Fe日d Sci Technol 6, 377-386

Mandell IB, Christison GI, Nicholson HH, Coxworth EC (1988) The effect of variation in the water content of wheat straw before ammoniation on its nutritive value for beef cattle. Anim Feed Sci Technol 20, 111-124

Mann ME, Cohen RDH, Kernan JA, Nicholson HH, Christensen DA, Smart ME (1988) The feeding value of ammoniated flax straw, wheat straw and wheat chaff for beef cattle. Anim Feed Sci Technol 21, 57-66

Mehrez AZ, Ørskov ER (1977) A study of the artificial fibre bag technique for determining the digestibility of feeds in the rumen. $J$ Agric Sci (Camb) 88, 645-650

Ørskov ER, Reid GW, Holland SM, Tait CAG, Lee NH (1983) The feeding value for ruminants of straw and whole-crop barley and oats treated with anhydrous or aqueous ammonia or urea. Anim Feed Sci Technol 8, 247-257

SAS/STAT (1987) User's Guide Release 6.04. SAS Institute Inc, Cary, NC, USA 
Sokal RR, Rohif FJ (1979) Biometria; Principios y Métodos Estadísticos en la Investigación Biológica. H Blume, Madrid, 817 pp

Solaiman SG, Horn GW, Owens FN (1979) Ammonium hydroxide treatment on wheat straw. J Anim Sci 49(3), 802-808

Steel RGD, Torrie JH (1980) Principles and Procedures of Statistics: A Biometrical Approach. McGraw-Hill Book Co, NY, 2nd edn, 622 pp

Sundstøl F, Owen E (1984) Straw and Other Fibrous By-Products as Feed. Elsevier, Amsterdam, $604 \mathrm{pp}$

Tilley JM, Terry RA (1963) A two stage technique for the in vitro digestion of forge crops. $J$ Br Grassld Soc 18, 104-111

Waiss AC, Guggolz J, Kohler GO, Walker HG, Garrett WN (1972) Improving digestibility of straws for ruminant feed by aqueous ammonia. J Anim Sci 35(1), 109-112
Wanapat M, Sundstøl F, Garmo TH (1985) A comparison of alkali treatment methods to improve the nutritive value of straw. I. Digestibility and metabolizability. Anim Feed Sci Technol 12, 295-309

Watt GW, Chrisp JD (1954) The determination of urea in feeding stuffs. Analyt Chem 26, 452

Williams PEV, Innes GM, Brewer A (1984a) Ammonia treatment of straw via the hydrolysis of urea. I. Effects of dry matter and urea concentrations on the rale of hydrolysis of urea. Anim Feed Sci Technol 11, 103-113

Williams PEV, Innes GM, Brewer A (1984b) Ammonia treatment of straw via the hydrolysis of urea. II. Additions of soya bean (urease), sodium hydroxide and molasses; effects on the digestibility of urea-treated straw. Anim Feed Sci Technol 11, 115-124 